\title{
Somatic cell count in the diagnosis of subclinical mastitis in sheep of different breeds
}

\section{Contagem de células somáticas para o diagnóstico da mastite subclínica ovina em diferentes raças}

\author{
Luiz Francisco Zafalon ${ }^{*}$; Raul Costa Mascarenhas Santana²; Sérgio Novita \\ Esteves $^{1}$; Guilherme Aparecido Fim Júnior ${ }^{3}$
}

\begin{abstract}
The aims of this study were to determine the occurrence of subclinical mastitis in sheep of different breeds and the values for somatic cell count (SCC) in milk for the diagnosis of the disease at lactation and weaning, a fundamental prerequisite for identifying animals in need of control measures. Milk samples were obtained from 1,457 mammary halves of Santa Inês, Texel, Ile de France, and Dorper sheep at two different periods, during the second week of lactation and at weaning. After teats antisepsis, the samples were collected, and identification of the infectious etiology of mastitis and determination of SCC were performed. Microorganisms were identified in 117/762 (15.3\%) mammary halves in the second week of lactation and in 86/694 (12.4\%) at weaning. Coagulase-negative staphylococci (CoNS) were the etiological agents with the highest incidence alone and in association with other microorganisms, with percentages of $58.1 \%$ and $60.6 \%$, respectively. The Santa Inês presented a higher incidence of subclinical mastitis when compared to the other breeds. The cut-off values of SCC for subclinical mastitis were determined at both sampling periods and varied according to stage of lactation, as well breed. These results illustrate the lack of a universal value that can be used for the diagnosis of mastitis and suggests the need for permanent follow-up in herds in order to control the disease.
\end{abstract}

Key words: Diagnostic tests. Milk. Sheep.

\section{Resumo}

Os objetivos do trabalho foram estabelecer a ocorrência da mastite subclínica em ovelhas de diferentes raças e os respectivos valores de triagem da contagem de células somáticas (CCS) no leite para o diagnóstico da doença durante a lactação e ao desmame, um pré-requisito fundamental para a identificação dos animais para o estabelecimento de medidas de controle. As amostras de leite foram obtidas de 1.457 metades mamárias de ovelhas das raças Santa Inês, Texel, Ile de France e Dorper, em dois diferentes períodos, durante a segunda semana de lactação e ao desmame. Após a antissepsia dos tetos, as amostras de leite foram colhidas para identificação da etiologia infecciosa dos casos de mastite e determinação da CCS. Dentre as metades mamárias investigadas, $117 / 763(15,3 \%)$ apresentaram micro-organismos no leite na segunda semana de lactação e 86/694 (12,4\%) apresentaram resultados microbiológicos positivos ao desmame. Estafilococos coagulase-negativos (ECN) foram os agentes etiológicos com maior ocorrência isoladamente e em associação com outros micro-organismos, $58,1 \%$ e $60,6 \%$, respectivamente. A raça Santa Inês apresentou maior ocorrência de mastite subclínica, quando

Pesquisadores, Embrapa Pecuária Sudeste, CPPSE, São Carlos, SP, Brasil. 1uiz.zafalon@embrapa.br; sergio.esteves@embrapa.br

2 Analista, Embrapa Pecuária Sudeste, CPPSE, São Carlos, SP, Brasil. E-mail: raul.mascarenhas@embrapa.br

3 Discente, Programa de Pós-Graduação em Medicina Veterinária Preventiva, Faculdade de Ciências Agrárias e Veterinárias, Universidade Estadual Paulista, FCAV/UNESP, Jaboticabal, SP, Brasil. E-mail: guilhermejunior10@hotmail.com

* Author for correspondence 
comparada às outras raças. Diferentes pontos de corte para CCS foram determinados em ambos os períodos. Os valores das contagens celulares para a triagem da mastite subclínica nas ovelhas variaram de acordo com a fase da lactação em que as amostras foram obtidas, assim como com as raças dos animais, o que denota não existir um valor universal que possa ser usado para o diagnóstico da mastite, sugerindo a necessidade de acompanhamento técnico permanente nos rebanhos para o controle da doença.

Palavras-chave: Leite. Ovelhas. Testes diagnósticos.

\section{Introduction}

Mastitis is classically defined as an inflammation of the mammary gland, characterized by physical, chemical, and microbiological alterations in the milk. The inflammatory process may be caused by trauma or physiological or allergic alterations; however, it mainly occurs due to infection by microorganisms, predominantly bacteria of the genus Staphylococcus (DRESCHER et al., 2010).

In sheep farming, mastitis compromises the productivity of the herd, causing economic losses due to loss or partial compromise of the mammary gland, caused by alterations of its functional capacity, and it can even lead to the death of the animal. In addition, the disease impedes the development of lambs due to reduced milk production and changes in milk composition, which may lead to starvation deaths and reduced growth if supplementary feeding is not given. As a result, mastitis leads to an increase in expense for veterinary care, medications, and labor (COUTINHO et al., 2006; PEREIRA et al., 2014).

With the change from the extensive breeding system to a more intensive model, greater investments in genetic improvement and crossbreeding have increased interest in aspects related to the composition and production of milk (FONSECA et al., 2011). Regarding breeding sheep for meat production, the study of aspects related to the mammary gland, aiming to select breeds with less mastitis to avoid losses in animal production, is also relevant.

Somatic cell count (SCC) is a method used to diagnose subclinical mastitis, a form of the disease where macroscopic signs in the sheep, or specifically in the mammary gland, are not visualized. The greater the prevalence of subclinical mastitis, the greater the possibility that it will evolve into clinical disease. However, the response of the mammary gland in different breeds to the invasion of microorganisms that cause mastitis is not known. Therefore, the aims of this study were to establish the occurrence rate of subclinical mastitis in sheep of different breeds and to determine the values for SCC of milk in the sheep during lactation and weaning.

\section{Material and Methods}

The study was carried out in an experimental herd of Santa Inês, Texel, Ile de France, and Dorper sheep, located in the city of São Carlos, São Paulo, between September 2013 and October 2014. All sheep that produced milk samples were submitted to the same semi-intensive management system. The animals were kept in Tanzania grass paddocks and supplemented during the dry season with a daily supply of corn silage. The sheep also had free access to mineral salt and water.

Milk samples were collected from all sheep in the second week of lactation and on the day after weaning of the lambs (at the $96^{\text {th }}$ day after lambing, on average). The Texel, Ile de France, and Dorper breeds were in their first lambing, while the Santa Inês sheep were between their first and sixth lactations. The presence of visual inflammatory changes of the mammary gland and/or macroscopic signs of milk alterations served as the basis for the classification of clinical mastitis (GARINO JÚNIOR et al., 2006). 
The sheep with clinical mastitis were then separated and not used for milk sampling.

Samples for microbiological analyses were collected into sterile test tubes from each mammary half, in duplicate, after antisepsis of the teats with $70 \%(\mathrm{v} / \mathrm{v})$ ethyl alcohol. After collection, the samples were immediately sent to the laboratory, where the microbiological analyses were performed to determine the infectious etiology of the disease. The samples were seeded on the surface of culture Petri dishes with 5\% sheep blood agar and MacConkey agar. After incubation at $37{ }^{\circ} \mathrm{C}$ for 24 to 72 hours, the microorganisms were identified by macroscopic characterization of the colonies, such as morphology, pigment production, and hemolysis, as well as morphotintorial and biochemical characteristics. When three or more types of colonies were isolated from the same sample, they were considered contamination. Coagulasenegative staphylococci (CoNS) were submitted to the novobiocin resistance test for differentiation into two subgroups: novobiocin-resistant coagulasenegative staphylococci (NRCoNS) and novobiocinsensitive coagulase-negative staphylococci (NSCoNS) (KONEMAN et al., 2001). The interpretation of the microbiological test results was performed according to Harmon et al. (1990). The sample was considered positive when one or more colonies were the same, with the same morphology, size, pigmentation, and type of hemolysis, and no more than two types of colonies were present.

The samples of milk for SCC determination were collected in $60 \mathrm{~mL}$ plastic bottles with bronopol preservative and were sent to a reference laboratory recognized by the Ministry of Agriculture, Livestock and Food Supply, located in the city of Piracicaba, São Paulo. SCC was obtained using the electronic flow cytometry technique, Somacount 300 (Bentley Instruments ${ }^{\circledR}$ ) calibrated for bovine milk analysis. When the amount of milk required for the evaluation of SCC was not acquired, the animal was disregarded for the analysis of the results.
Different cut-off values for SCC were calculated according to the time (second week of lactation and weaning) the samples were obtained. These cut-off values were derived by subtracting one from the sum of the susceptibility and specificity and were used to define the optimal value for SCC for each sheep breed (SCHISTERMAN et al., 2005). The calculations were made using an online tool provided by AusVet Animal Health Services (2015), and SCC of the animals with and without identification of microorganisms in milk were analyzed. All samples of Ile de France, Texel, and Dorper breeds with $\mathrm{SCC}>1,000,000 \mathrm{~mL}^{-1}$ cells, even with no microbiological isolation, were considered positive in the calculation of the values (BERTHELOT et al., 2006). The occurrence of mastitis in the different breeds was then compared by means of logistic regression, using Fisher score as the optimization technique (SAMPAIO, 1998).

\section{Results and Discussion}

In the second week of lactation, 763 mammary halves were evaluated. Of these, 117 (15.3\%) presented positive results on laboratory testing for microorganisms (Table 1).

During the weaning phase, 694 mammary halves were evaluated, of which $86(12.4 \%)$ presented microbiological isolates. Microorganisms isolated, alone or in association, are shown in Table 2.

Among the 1,457 mammary halves investigated in both periods, $203(13.9 \%)$ were positive on the microbiological examinations. The most frequent etiologic agents were CoNS, with percentages alone and in association with other bacteria of $58.1 \%$ and $60.6 \%$, respectively. These results support those of other authors who have reported CoNS as the main bacteria responsible for mastitis in sheep raised for meat production (MORONI et al., 2007; OLECHNOWICZ; JASKOWSKI, 2014; PEREIRA et al., 2014; SANTANA et al., 2013). Hartman et al. (2009) and Guaraná et al. (2011) reported 
percentages of $16.2 \%$ and $15.9 \%$ for Streptococcus spp., respectively. These percentages are similar to those reported here in the second week of lactation, when only the samples with positive microbiological results were considered (Table 1). However, the occurrence of Streptococcus spp. at the weaning phase was higher than that at the second week of lactation $(27.9 \%)$, when only the positive samples were considered. Before weaning, the herd was periodically subjected to management activities at the property, which may have caused stress and increased the susceptibility of the sheep to different pathogens. Although the bacterial species were not identified in this study, environmental streptococci are the main suspects, since the management of the animals was carried out in sheds that, although cleaned frequently, had feces and elevated humidity.

Table 1. Microorganisms isolated in samples of milk from mammary halves of different sheep breeds during the second week of lactation.

\begin{tabular}{lcccccccccc}
\hline \multirow{2}{*}{\multicolumn{1}{c}{ Microorganisms }} & \multicolumn{2}{c}{ Santa Inês } & \multicolumn{3}{c}{ Texel } & \multicolumn{2}{c}{ Ile de France } & \multicolumn{2}{c}{ Dorper } & \multicolumn{2}{c}{ Total } \\
\cline { 2 - 11 } & $\mathrm{N}$ & $\%$ & $\mathrm{~N}$ & $\%$ & $\mathrm{~N}$ & $\%$ & $\mathrm{~N}$ & $\%$ & $\mathrm{~N}$ & $\%$ \\
\hline NSCoNS $^{1}$ & 55 & 13.7 & 2 & 1.7 & 5 & 4.2 & 1 & 0.8 & 63 & 8.2 \\
NRCoNS $^{2}$ & 17 & 4.2 & 3 & 2.5 & 0 & 0.0 & 0 & 0.0 & 20 & 2.6 \\
Streptococcus spp. & 10 & 2.5 & 2 & 1.7 & 2 & 1.7 & 2 & 1.7 & 16 & 2.1 \\
Corynebacterium spp. $^{\text {CoPS }}$ & 4 & 1.0 & 0 & 0.0 & 1 & 0.8 & 0 & 0.0 & 5 & 0.7 \\
Enterobacteria & 3 & 0.8 & 0 & 0.0 & 2 & 1.7 & 0 & 0.0 & 5 & 0.7 \\
Staphylococcus aureus & 3 & 0.8 & 0 & 0.0 & 2 & 1.7 & 0 & 0.0 & 5 & 0.7 \\
NSCoNS/CoPS & 1 & 0.2 & 0 & 0.0 & 0 & 0.0 & 1 & 0.8 & 2 & 0.3 \\
Negative Samples & 1 & 0.2 & 0 & 0.0 & 0 & 0.0 & 0 & 0.0 & 1 & 0.1 \\
\hline Total & 308 & 76.6 & 113 & 94.2 & 108 & 90.0 & 117 & 96.7 & 646 & 84.7 \\
\hline
\end{tabular}

${ }^{1}$ Novobiocin-sensitive coagulase-negative staphylococci; ${ }^{2}$ Novobiocin-resistant coagulase-negative staphylococci; ${ }^{3}$ Coagulasepositive staphylococci.

Table 2. Microorganisms isolated in samples of milk from mammary halves of different sheep breeds at the end of lactation, immediately after weaning.

\begin{tabular}{lcccccccccc}
\hline \multirow{2}{*}{\multicolumn{1}{c}{ Microorganisms }} & \multicolumn{2}{c}{ Santa Inês } & \multicolumn{2}{c}{ Texel } & \multicolumn{2}{c}{ Ile de France } & \multicolumn{2}{c}{ Dorper } & \multicolumn{2}{c}{ Total } \\
\cline { 2 - 11 } & $\mathrm{N}$ & $\%$ & $\mathrm{~N}$ & $\%$ & $\mathrm{~N}$ & $\%$ & $\mathrm{~N}$ & $\%$ & $\mathrm{~N}$ & $\%$ \\
\hline NSCoNS $^{1}$ & 26 & 7.6 & 1 & 0.9 & 4 & 3.8 & 1 & 0.8 & 32 & 4.6 \\
Streptococcus spp. $_{\text {Enterobacteria }}^{16}$ & 4.7 & 3 & 2.6 & 2 & 1.9 & 3 & 2.3 & 24 & 3.5 \\
Corynebacterium spp. & 5 & 1.4 & 1 & 0.9 & 0 & 0.0 & 0 & 0.0 & 6 & 0.9 \\
Staphylococcus aureus & 3 & 0.9 & 0 & 0.0 & 1 & 1.0 & 2 & 1.5 & 6 & 0.9 \\
NRCoNS & 3 & 0.9 & 0 & 0.0 & 1 & 1.0 & 1 & 0.8 & 5 & 0.7 \\
NSCoNS/Streptococcus spp. & 3 & 0.9 & 0 & 0.0 & 0 & 0.0 & 0 & 0.0 & 3 & 0.4 \\
CoPS $^{3}$ & 3 & 0.9 & 0 & 0.0 & 0 & 0.0 & 0 & 0.0 & 3 & 0.4 \\
NSCoNS /S. aureus & 2 & 0.6 & 0 & 0.0 & 1 & 1.0 & 0 & 0.0 & 3 & 0.4 \\
& 1 & 0.3 & 0 & 0.0 & 0 & 0.0 & 0 & 0.0 & 1 & 0.1 \\
& & & & & & & & & & continue
\end{tabular}


continuation

\begin{tabular}{lcccccccccc} 
CoPS Streptococcus spp. & 1 & 0.3 & 0 & 0.0 & 0 & 0.0 & 0 & 0.0 & 1 & 0.1 \\
S. aureus/Streptococcus spp. & 1 & 0.3 & 0 & 0.0 & 0 & 0.0 & 0 & 0.0 & 1 & 0.1 \\
S. aureus/Enterobacteria & 1 & 0.3 & 0 & 0.0 & 0 & 0.0 & 0 & 0.0 & 1 & 0.1 \\
Negative Samples & 278 & 81.0 & 111 & 95.7 & 95 & 91.3 & 124 & 94.7 & 608 & 87.6 \\
\hline Total & 343 & 100.0 & 116 & 100.0 & 104 & 100.0 & 131 & 100.0 & 694 & 100.0 \\
\hline
\end{tabular}

${ }^{1}$ Novobiocin-sensitive coagulase-negative staphylococci; ${ }^{2}$ Novobiocin-resistant coagulase-negative staphylococci; ${ }^{3} \mathrm{Coagulase-}$ positive staphylococci.

Bacteria like CoNS are important because of problems related to aspects of public health. Coutinho et al. (2006) found strains of CoNS that were resistant to various antimicrobials used in veterinary medicine, including beta-lactams. Onni et al. (2011) identified two samples of S. epidermidis in sheep that were resistant to methicillin, and both exhibited the mecA gene, which is related to the emergence of resistance to methicillin and oxacillin. In addition, other factors may favor the maintenance of CoNS in the host, such as the capacity for the formation of biofilms that cause adherence mediated by an intracellular polysaccharide adhesion. Dall Agnol et al. (2013) investigated biofilm production and the presence of the $i c a \mathrm{D}$ gene. Among the different techniques used for detection, biofilms were produced by $2.8 \%$ to $27.8 \%$ of the isolates, whereas the ica $\mathrm{D}$ gene was observed in only two of them $(5.6 \%)$. The majority $(80 \%)$ of the isolates were classified as CoNS.

The novobiocin disk test was used in this study for differentiation of CoNS species. It is useful for differentiating resistant microorganisms in vitro, rarely found in human clinical samples, from those that do not have resistance (FARIÑA et al., 2005). In vitro susceptibility to novobiocin has been proposed as a criterion for CoNS classification in sheep, since it is associated with pathogenicity. CoNS would then be divided into novobiocin-resistant coagulasenegative staphylococci (NRCoNS), which are less prevalent pathogens with less negative effects on milk production, and novobiocin-sensitive coagulase-negative staphylococci (NSCoNS), which are considered pathogens of greater importance (GONZALO et al., 2002). Isolated staphylococci with susceptibility to novobiocin have been responsible for clinical alterations of the mammary gland in sheep, unlike those resistant to novobiocin. The increased occurrence of staphylococci with susceptibility to novobiocin, when compared to those resistant to this active principle, has also been reported by other authors (ARIZNABARRETA et al., 2002; ZAFALON et al., 2012).

When comparing frequencies of cases of subclinical mastitis between breeds, Santa Inês presented a higher occurrence of the disease $(\mathrm{p}<0.05$; non-tabulated data). In spite of its ability to produce meat, characteristics of the Bergamáza dairy breed in its genetic composition make the Santa Inês sheep an excellent milk producer but also increase the occurrence of mastitis (MELO et al., 2008). The animals in the present study were enclosed during the night in sheds with a dirt floor. The practice of keeping animals confined within overnight facilities increases the exposure of females to a greater number of disease-causing agents, due to accumulation of organic matter and increased humidity and temperature. These conditions favor the multiplication of environmental agents that cause mastitis (MOTA, 2008).

Tools intended to describe the performance of a diagnostic test aim to determine a cut-off value so that an individual with measurements less than or equal to the cut-off value is classified as non-diseased, and an individual with a test response greater than the cut-off point is classified as sick (MARTINEZ et al., 
2003). The values of SCC in milk when screening for subclinical mastitis in lactation and weaning in the different breeds are presented in Table 3, with their respective susceptibilities and specificities.

The values of SCC in milk at weaning were higher than those at the second week of lactation, except for the Ile de France breed. At weaning, the sheep likely produce a smaller amount of milk, which elevates the SCC value required for the identification of a mammary half with mastitis. In addition, this lower milk yield at weaning influences the lower incidence of subclinical mastitis (PEREIRA et al., 2014) and indicates the need for greater attention to SCC levels at this stage. Counts classifying cases with disease during lactation will not necessarily be considered diagnostic for mastitis at weaning.

Table 3. Established cut-off values of somatic cell count in milk for the diagnosis of subclinical mastitis in sheep of different breeds during lactation and weaning.

\begin{tabular}{|c|c|c|c|c|c|c|}
\hline \multirow[b]{2}{*}{ Breeds } & \multicolumn{3}{|c|}{ Lactation } & \multicolumn{3}{|c|}{ Weaning } \\
\hline & $\mathrm{SCC}^{1}$ & $\mathrm{SU}^{2}$ & $\mathrm{SP}^{3}$ & $\mathrm{SCC}$ & $\mathrm{SU}$ & SP \\
\hline Santa Inês & 487,000 & 77.0 & 76.4 & $1,171,000$ & 74.2 & 92.5 \\
\hline Texel & 419,000 & 63.6 & 97.2 & 820,000 & 100.0 & 100.0 \\
\hline Ile de France & 781,000 & 92.9 & 99.0 & 554,000 & 66.7 & 98.9 \\
\hline Dorper & $1,062,000$ & 62.5 & 100.0 & $1,276,000$ & 88.9 & 100.0 \\
\hline
\end{tabular}

${ }^{1}$ Somatic cell count $\left(\mathrm{mL}^{-1}\right.$ cells); ${ }^{2}$ Susceptibility $(\%) ;{ }^{3}$ Specificity $(\%)$.

Nunes et al. (2008) followed Santa Inês sheep throughout lactation and reported that the cut-off value of $500,000 \mathrm{~mL}^{-1}$ cells in milk was ideal for the diagnosis of mastitis. Blagitz et al. (2008) reported a median SCC close to 850,000 cells $\mathrm{mL}^{-1}$ in milk of Santa Inês sheep, 12 days prior to weaning, with udders and/or teats that were altered on inspection and normal to palpation and also bacteriologically positive. Other authors also considered only higher values for SCC, such as values greater than $1,000,000 \mathrm{~mL}^{-1}$ cells, as characteristic of mastitis in sheep, while values between 500,000 and 1,000,000 $\mathrm{mL}^{-1}$ cells indicated suspected cases (BERTHELOT et al., 2006; FRAGKOU et al., 2014). A similar cutoff point for the Santa Inês and Texel breeds in the lactation period of approximately $400,000 \mathrm{~mL}^{-1}$ cells was reported by Kern et al. (2013), and according to their report, this limit would be the most appropriate for the screening of cases of subclinical mastitis in sheep of breeds that are raised for meat production.

In this report, few positive results were found in the microbiological examinations of the milk samples from the Texel, Ile de France, and Dorper sheep, which would make it difficult to calculate the values for SCC in the screening for subclinical mastitis, according to the methodology adopted. For this reason, all samples of milk that presented SCC greater than $1,000,000 \mathrm{~mL}^{-1}$ cells were considered positive for the calculations of subclinical mastitis, even when negative for microorganisms. This value was chosen based on previous literature (BERTHELOT et al., 2006; CLEMENTS et al., 2003; HUSSEIN et al., 2015). The absence of microorganisms in milk samples with high SCC may have several causes. Limitations of diagnostic tools for microbiology in discriminating between infected and uninfected mammary glands may be one of them (GUERREIRO et al., 2013). The debate on the significance of increased SCC in sheep's milk for the diagnosis of mastitis is still ongoing. Studies related to proteomic analysis of sheep milk confirm that the increase of SCC is not always associated with proteins that characterize infection. Stressful conditions of cellular differentiation, 
problems in the glandular metabolism possibly related to hormonal changes, and even previous infections may be related to the increase of SCC (CHIARADIA et al., 2013). Interestingly, high SCC levels without microbiological isolation occurred in all breeds, except the Santa Inês sheep.

The susceptibility and specificity of SCC vary according to the cut-off values used to classify mastitis. After analyzing 393 mammary halves of Santa Inês and Morada Nova sheep during the weaning period, Santana (2014) reported a susceptibility of $86.6 \%$ when using a cut-off value of $200,000 \mathrm{~mL}^{-1}$ cells, and the specificity remained greater than $80 \%$ in counts higher than 400,000 $\mathrm{ml}^{-1}$ cells. In the present study, the cut-off values at weaning were higher than those presented by Santana (2014). However, SCC susceptibility for the Texel and Dorper breeds was still high at 100.0 and $88.9 \%$, respectively. During lactation, cut-off values above 400,000 and below 500,000 $\mathrm{mL}^{-1}$ cells for the Santa Inês and Texel breeds had susceptibilities below $80 \%$. Hussein et al. (2015) reported that a value of $\mathrm{SCC} \geq 400,000 \mathrm{~mL}^{-1}$ cells in Ossimi sheep in Egypt presented 90\% susceptibility and $88 \%$ specificity, and, therefore, had a higher probability of detecting animals with subclinical mastitis.

The SCC used as cut-off values in detecting mammary halves with subclinical mastitis vary according to the proportion of affected animals and the infectious agents present in the herd. In the present study, the susceptibility and specificity of the SCC were used to determine the cut-off values. A test for the diagnosis of subclinical mastitis should demonstrate susceptibility that is sufficient to detect most of the sheep with the disease. It should also have adequate specificity, so excessive amounts of false-positives are not generated, since microbiological examinations to confirm the disease are not always performed due to expense, time required, and impracticality for large herds. The standard microscopic method for determining
SCC was not used in the present study. Instead, we opted for a technique that was more practical and less time-consuming for situations where evaluation of many animals at the same time is necessary. The electronic counts were carried out on a device calibrated for bovine milk, since the laboratory responsible for the high demand of milk analyses of this species could not change its protocol. This factor is a reality for sheep farmers so that they can obtain necessary information concerning mastitis in their herds.

Diagnostic methods available for the identification of mastitis in sheep are not species specific, as they are generally used in cattle. Among the methods, SCC is efficient in the identification of mammary halves with inflammatory processes in sheep. Several factors may influence milk SCC, such as lactation phase, number of previous lactations, milk fraction, stress, and nutritional status of the animal (ANDERSON et al., 2005; BERGONIER; BERTHELOT, 2003). In this study, all factors were consistent among the sheep, except for the number of lactations in the Santa Inês breed, which had animals with up to six lactations, while all other breeds were in their first lambing. However, since microbiological test results were used for calculations of the values for SCC, the number of lambings did not influence the results. This was confirmed by previous evaluation through a factorial analysis between the number of Santa Inês breed lactations and subclinical mastitis, where the interaction between disease and number of lactations did not influence SCC.

In the future, SCC information from herds of different breeds should be further evaluated, so that crossbreeding can be developed to increase the genetic potential for resistance to mastitis. Moreover, studies on mastitis diagnostic procedures may allow for treatment of the disease before the emergence of clinical signs that compromise the health of the sheep. 


\section{Conclusions}

Santa Inês sheep showed a higher occurrence of subclinical mastitis in relation to the other breeds, and the predominant infectious etiology was composed of CoNS. The values for the cell counts in the screening of subclinical mastitis in the sheep varied according to the stage of lactation in which the samples were obtained and with the breed. This supports the absence of a universal SCC cut-off value that can be used for the diagnosis of mastitis.

\section{Acknowledgements}

We would like to thank Carolina Orlando Vaso and Nahryda Samara dos Santos Lopes for collaborating in the processing of milk samples for microbiological diagnosis and the São Paulo Research Foundation (FAPESP) for the Master's Degree Scholarship for Guilherme Aparecido Fim Junior (FAPESP - 2013/23054-9).

\section{References}

ANDERSON, D. E.; HULL, B. L.; PUGH, D. G. Enfermidades da glândula mamária. In: PUGH, D. G. Clínica de ovinos e caprinos. São Paulo: Roca, 2005. p. 379-399.

ARIZNABARRETA, A.; GONZALO, C.; PRIMITIVO, F. S. Microbiological quality and somatic cell count of ewe milk with special reference to Staphylococci. Journal of Dairy Science, Champaign, v. 85, n. 6, p. 1370-1375, 2002.

AUSVET ANIMAL HEALTH SERVICES. Calculate test sensitivity and specificity and ROC curves. Canberra: [s.n.], 2015. Available at: <http://epitools.ausvet.com.au/ content.php?page $=$ ROC_curves $>$. Accessed at: 29 maio 2015.

BERGONIER, D.; BERTHELOT, X. New advances in epizootiology and control of ewe mastitis. Livestock Production Science, Amsterdam, v. 79, n. 1, p. 1-16, 2003.

BERTHELOT, X.; LAGRIFFOUL, G.; CONCORDET, D.; BARILLET, F.; BERGONIER, D. Physiological and pathological thresholds of somatic cell counts in ewe milk. Small Ruminant Research, Amsterdam, v. 62, n. 1-2, p. 27-31, 2006.
BLAGITZ, M. G.; BATISTA, C. F.; SOUZA, F. N.; BENITES, N. R.; MELVILLE, P. A.; STRICAGNOLO, C. R.; RICCIARDI, M.; GOMES, V.; AZEVEDO, M. R.; SANCHES, B. G. S.; DELLA LIBERA, A. M. M. P. Perfil celular e microbiológico do leite de ovelhas Santa Inês no período lactante e pós-desmame. Pesquisa Veterinária Brasileira, Rio de Janeiro, v. 28, n. 9, p. 417 422, 2008.

CHIARADIA, E.; VALIANI, A.; TARTAGLIA, M.; SCOPPETTA, F.; RENZONE, G.; ARENA, S.; AVELLINI, L.; BENDA, S.; GAITI, A.; SCALONI, A. Ovine subclinical mastitis: proteomic analysis of whey and milk fat globules unveils putative diagnostic biomarkers in milk. Journal of Proteomics, Valência, v. 83, p. 144-159, 2013.

CLEMENTS, A. C. A.; TAYLOR, D. J.; FITZPATRICK, J. L. Evaluation of diagnostic procedures for subclinical mastitis in meat-producing sheep. Journal of Dairy Research, Cambridge, v. 70, n. 2, p. 139-148, 2003.

COUTINHO, D. A.; COSTA, J. N.; RIBEIRO, M. G.; TORRES, J. A. Etiologia e sensibilidade antimicrobiana in vitro de bactérias isoladas de ovelhas da raça Santa Inês com mastite subclínica. Revista Brasileira de Saúde e Produção Animal, Salvador, v. 7, n. 2, p. 139-151, 2006.

DALL AGNOL, A. M.; CAVALCANTE, M. B.; FRANÇA, C. A.; KREWER, C. C.; QUEIRÓS, A. A.; COSTA, M. M.; BRAGANÇA, J. F. M.; GIRARDINI, L. K. Caracterização fenotípica e molecular de isolados de Staphylococcus spp. obtidos de leite de ovelhas do Município de Chapecó-SC. Semina: Ciências Agrárias, Londrina, v. 34, n. 1, p. 311-322, 2013.

DRESCHER, G.; MATTIELLO, S. P.; PEIXOTO, R. M.; VARGAS, A. C.; MACIEL, M. N.; COSTA, M. M. Caracterização bioquímica e perfil de sensibilidade de agentes bacterianos isolados de mastite subclínica ovina na região oeste de Santa Catarina. Ciência Animal Brasileira, Goiânia, v. 11, n. 1, p. 188-193, 2010.

FARIÑA, N.; SANABRIA, R.; FIGUEREDO, L.; RAMOS, L.; SAMUDIO, M. Staphylococcus saprophyticus como patógeno urinário. Memorias del Instituto de Investigaciones en Ciencias de La Salud, San Lorenzo, v. 1, n. 1, p. 31-33, 2005.

FONSECA, J. F.; BRUSCHI, J. H.; MARINHO, A. C. S.; RODRIGUES, I. M. Produção de caprinos e ovinos de leite. Juiz de Fora: EMBRAPA Gado de Leite, 2011. p. 193-212.

FRAGKOU, I. A.; BOSCOS, C. M.; FTHENAKIS, G. C. Diagnosis of clinical or subclinical mastitis in ewes. Small Ruminant Research, Amsterdam, v. 118, n. 1-3, p. 86-92, 2014. 
GARINO JÚNIOR, F.; WATANABE, E. T.; SANTOS, F. G. B.; BALBINO, T. C. L.; COSTA, E. O. Eficácia terapêutica em mastite clínica e análise de fatores preditivos. Revista Napgama, São Paulo, v. 9, n. 2, p. 9-16, 2006.

GONZALO, C.; ARIZNABARRETA, A.; CARRIEDO, J. A.; PRIMITIVO, F. S. Mammary pathogens and their relationship to somatic cell count and milk yield losses in dairy ewes. Journal of Dairy Science, Champaign, v. 85, n. 6, p. 1460-1467, 2002.

GUARANÁ, E. L. S.; SANTOS, R. A.; CAMPOS, A. G. S. S.; SILVA, N. S.; AFONSO, J. A. B.; MENDONÇA, C. L. Dinâmica celular e microbiológica do leite de ovelhas Santa Inês acompanhadas durante a lactação. Pesquisa Veterinária Brasileira, Rio de Janeiro, v. 31, n. 10, p. 851-858, 2011.

GUERREIRO, O.; VELEZ, Z.; ALVARENGA, N.; MATOS, C.; DUARTE, M. Molecular screening of ovine mastitis in different breeds. Journal of Dairy Science, Champaign, v. 96, n. 2, p. 752-760, 2013.

HARMON, R. J.; EBERHART, R. J.; JASPER, D. E.; LANGLOIS, B. E.; WILSON, R. A. Microbiological procedures for the diagnosis of bovine udder infections. $3^{\text {th }}$ ed. Arlington: National Mastitis Council, 1990. 34 p.

HARTMAN, M.; BOLSANELLO, R. X.; DOMINGUES, P. F.; MELLO JÚNIOR, A. S.; LANGONI, H. Efeito da mastite sobre a contagem de células somáticas (CCS) em ovelhas da raça Bergamácia. Veterinária e Zootecnia, Botucatu, v. 16, n. 1, p. 213-220, 2009.

HUSSEIN, H. A.; EL-KHABAZ, K. A. S.; MALEK, S. S. Is udder ultrasonography a diagnostic tool for subclinical mastitis in sheep? Small Ruminant Research, Amsterdam, v. 129, p. 121-128, 2015.

KERN, G.; TRAULSEN, I.; KEMPER, N.; KRIETER, J. Analysis of somatic cell counts and risk factors associated with occurrence of bacteria in ewes of different primary purposes. Livestock Science, Amsterdam, v. 157, n. 2-3, p. 597-604, 2013.

KONEMAN, E. W.; ALLEN, S. D.; JANDA, W. M.; SCHRECKENBERGER, P. C.; WINN JÚNIOR, W. C. W. Diagnóstico microbiológico. Texto e atlas colorido. $5^{\text {th }}$ ed. Rio de Janeiro: Medsi, 2001. 1465 p.

MARTINEZ, E. Z.; LOUZADA-NETO, F.; PEREIRA, B. B. A curva ROC para testes diagnósticos. Cadernos de Saúde Coletiva, Rio de Janeiro, v. 11, n. 1, p. 7-31, 2003.

MELO, C.; ALMEIDA, B. M.; OLIVEIRA, A. A.; AZEVEDO, H. C.; MELO, I. S. S.; MATA, S. S. Avaliação de uma metodologia profilática contra a mastite clínica em ovelhas da raça Santa Inês. Arquivo
Brasileiro de Medicina Veterinária e Zootecnia, Belo Horizonte, v. 60, n. 4, p. 1011-1013, 2008.

MORONI, P.; PISONI, G.; VARISCO, G.; BOETTCHER, P. Effect of intramammary infection in Bergamasca meat sheep on milk parameters and lamb growth. Journal of Dairy Research, Cambridge, v. 74, n. 3, p. 340-344, 2007.

MOTA, R. A. Aspectos epidemiológicos, diagnóstico e controle das mastites em caprinos e ovinos. Tecnologia \& Ciência Agropecuária, João Pessoa, v. 2, n. 3, p. $57-$ 61, 2008.

NUNES, G. R.; BLAGITZ, M. G.; FREITAS, C. B.; SOUZA, F. N.; RICCIARDI, M.; STRICAGNOLO, C. R.; SANCHES, B. G. S.; AZEDO, M. R.; SUCUPIRA, M. C. A.; DELLA LIBERA, A. M. M. P. Avaliação de indicadores inflamatórios no diagnóstico da mamite ovina. Arquivos do Instituto Biológico, São Paulo, v. 75, n. 3, p. 271-278, 2008.

OLECHNOWICZ, J.; JASKOWSKI, J. M. Mastitis in small ruminants. Medycyna Weterynaryjna, Lublin, v. 70, n. 2, p. 67-72, 2014.

ONNI, T.; SANNA, G.; LARSEN, J.; TOLA, S. Antimicrobial susceptibilities and population structure of Staphylococcus epidermidis associated with ovine mastitis. Veterinary Microbiology, Barcelona, v. 148, n. 1, p. 45-50, 2011.

PEREIRA, P. F. V.; STOTZER, E. S.; PRETTOGIORDANO, L. G.; MÜLLER, E. E.; LISBÔA, J. A. N. Fatores de risco, etiologia e aspectos clínicos da mastite em ovelhas de corte no Paraná. Pesquisa Veterinária Brasileira, Rio de Janeiro, v. 34, n. 1, p. 1-10, 2014.

SAMPAIO, I. B. M. Estatística aplicada à experimentação animal. Belo Horizonte: Fundação de Ensino e Pesquisa Veterinária e Zootecnia, 1998. 221 p.

SANTANA, R. C. M. Tratamento da mastite subclínica de ovelhas noperiodo secocomantimicrobianoconvencional e antimicrobiano nanoparticulado. 2014. Dissertação (Mestrado em Medicina Veterinária Preventiva) Faculdade de Ciências Agrárias e Veterinárias, UNESP, Campus de Jaboticabal. Jaboticabal.

SANTANA, R. C. M.;ZAFALON, L. F.; ESTEVES, S.N.; TANAKA, E. V.; PILON, L. E.; MASSA, R. Occurrence of etiologic agents causing subclinical mastitis in Morada Nova and Santa Ines ewes. ARS Veterinaria, Jaboticabal, v. 29 , n. 3, p. 148-152, 2013.

SCHISTERMAN, E. F.; PERKINS, N. J.; LIU, A.; BONDELL, H. Optimal cutpoint and its corresponding Youden index to discriminate individuals using pooled blood samples. Epidemiology, Herndon, v. 16, n. 1, p. 73-81, 2005. 
ZAFALON, L. F.; VERISSIMO, C. J.; MAMIZUKA, E. M.; MARTINS, K. B.; ALMEIDA, L. M.; VESCHI, J. L.

A. Estafilococos resistentes à oxacilina isolados em casos de mastite subclínica em ovinos. Arquivos do Instituto Biológico, São Paulo, v. 79, n. 1, p. 1-7, 2012. 